\title{
An Overlapping Legislative Authority: Parliament versus the Indonesian Constitutional Court
}

\author{
Ahmad Mustarudin Efendi* \\ DOI: https://doi.org/10.22304/pjih.v5n1.a3 \\ Submitted: October 23, 2017 | Accepted: April 20, 2018
}

\begin{abstract}
The Indonesian House of Representatives has an authority to form laws together with the President, which may limit the authority of the Constitutional Court. On the other hand, the Constitutional Court has an authority to examine the suitability of the law against the 1945 Constitution. These facts have triggered a dispute between the Parliament and the Constitutional Court. The topic of this article consists of two main points. The first, what is the task form and the authority of the Parliament and the Constitutional Court? The second, what is the ultra petita authority of the Constitutional Court that causes the redundancy of legislative authority between the Parliament and the Constitutional Court? The research results reveal that in the view of the trias politica theory, based on the principle of checks and balances, the legislation authority is entirely in the hands of legislative and executive. In addition, the basis of the overlapping of the authority between the House of Representatives and the Constitutional Court is related to the ultra petita of the Constitutional Court's decisions, which often makes new norms as a substitute for the norms that are canceled.
\end{abstract}

Keywords: Constitutional Court authority, inter-institutions dispute, parliament authority.

\section{Overlapping Kewenangan Legislasi antara Dewan Perwakilan Rakyat dan Mahkamah Konstitusi}

\begin{abstract}
Abstrak
Adanya kewenangan Dewan Perwakilan Rakyat (DPR) membentuk norma undang-undang bersama dengan Presiden yang dapat membatasi kewenangan Mahkamah Konstitusi (MK) dan adanya kewenangan $M K$ untuk menguji undang-undang terhadap Undang-Undang Dasar (UUD) menimbulkan sengketa antara DPR dan MK. Topik kajian dalam penulisan artikel ini terdiri dari, pertama bagaimana bentuk tugas dan kewenangan lembaga DPR dan MK? Dan kedua bagaimanakah kewenangan ultra petita MK yang menjadi penyebab timbulnya overlapping kewenangan legislasi lembaga DPR dan MK? Dari hasil penelitian ditemukan bahwa pandangan teori trias politica yang mendasarkan pada prinsip checks and balances menempatkan kewenangan legislasi berada sepenuhnya pada tangan legislatif dan eksekutif, selain itu yang menjadi dasar dari timbulnya overlap kewenangan DPR dan MK adalah kaitannya dengan ultra petita dalam putusan $M K$ yang seringkali membuat norma baru sebagai pengganti dari norma yang sudah dibatalkan.
\end{abstract}

Kata kunci: kewenangan DPR, kewenangan $M K$, sengketa lembaga. 


\section{A. Introduction}

The 1945 Constitution of the Republic of Indonesia (the 1945 Constitution) mentions that there are (at least) nine (9) state institutions directly receiving authority from the 1945 Constitution. They are (i) the House of Representative, (ii) the Regional Representative Council, (iii) the People's Consultative Assembly, (iv) the Audit Board of Indonesia, (v) President, (vi) the Vice President, (vii) the Supreme Court, (viii) the Constitutional Court, and (ix) the Judicial Commission. ${ }^{1}$

In addition to the nine institutions, there are also several institutions that are authorized by the 1945 Constitution. They are: (1) the Indonesian National Army; (2) the Indonesian National Police; (3) the Regional Government; and (4) the Political Parties. Furthermore, the constitution also mentions some unnamed institutions that the functions are mentioned implicitly: (1) a Central Bank (it is later named "Bank Indonesia"), and (ii) a general election commission (To be precise, it is not a name because it is written in lowercase). Neither Bank Indonesia nor the General Election Commission, which now conducts electoral activities, are independent institutions, which gain their authority from laws. ${ }^{2}$

Therefore, it can be concluded that the principle of Trias Politica in Indonesia is not applied purely. However, the post-amendment 1945 Constitution implicitly contains the spirit of this theory, although it is not consistently applied. For example, it puts legislative functions in the hands of the Parliament, the law implementation function in the executive (namely President and Vice President), and the judiciary function in the hands of the Supreme Court (Mahkamah Agung) and the Constitutional Court (Mahkamah Konstitusi).

The amendment of the 1945 Constitution has given the House of Representatives the power to form laws. This provision indicates that the House of Representatives (DPR, Dewan Perwakilan Rakyat) is a legislative body in Indonesia. As a legislative body, it has legislative function, budget function, and supervisory function. According to Jimly Asshiddiqie, important changes in the formulations of the 1945 Constitution are a fundamental shifts in the legislative functions of the President's hand to the House of Representatives. ${ }^{3}$ Article 20(1) of the 1945 Constitution regulates "Dewan Perwakilan Rakyat memegang kekuasaan membentuk undang-undang" (The House of Representatives shall have the power to form a law); and Article 20(2) mentions "Setiap rancangan undang-undang dibahas oleh Dewan Perwakilan Rakyat dan Presiden untuk mendapat persetujuan bersama" (every draft of law is discussed by the House of Representatives and the President for mutual consent). Subsequently, Article 21 stipulates "Anggota Dewan Perwakilan Rakyat berhak mengajukan usul

\footnotetext{
Jimly Asshidiqqie, "Kedudukan Mahkamah Konstitusi Dalam Struktur Ketatanegaraan Indonesia”, http://www. iimlyschool.com, accessed on September 2017.

Ibid.

RR. Cahyowati (ed.), "Sengketa Kewenangan Antara Dewan Perwakilan Rakyat Dan Mahkamah Konstitusi Dalam Pembentukan Norma Hukum”, Jurnal Penelitian Universitas Mataram, Vol. 18, No. 2, 2014, p. 3.
} 
rancangan undang-undang" (members of the House of Representatives shall have the right to propose a draft law). ${ }^{4}$

The above description has shown that in the Indonesian constitutional system the authority to form laws ${ }^{5}$ lies in the hands of the legislature in a positive sense and exists in the hands of the executive in a negative sense. The executive can only file a bill but still must obtain legislative approval. This principle is in accordance with Trias Politica of Montesquieu.

However, in the course of the Indonesian administration, there are overlaps of authority to form legislation. These overlaps have occurred when there are several cases handled by the Constitutional Court and resulted in the Constitutional Court having to declare that a norm has no binding force and at its very least forces the institution to form a new norm with a reason to avoid legal vacancies because of the time to revise the law. The process of law production in the House usually takes a very long time. Moreover, when the Constitutional Court issue an ultra petita verdict in the form of new legal norms as a substitute for the legal norms that have been canceled, it has generated a reaction from the House of Representatives as an institution that holds the legislative power. This reaction arose because the Parliament felt its legislative authority based on the 1945 Constitution had been reduced, or taken, by the Constitutional Court through the ultra petita decision. ${ }^{6}$

To prevent the ultra petita decision made by the Constitutional Court in the formation of legal norms, the Parliament along with the President made changes to the Law Number 24 of 2003 on the Constitutional Court by endorsing and enacting Law Number 8 of 2011 on the Amendment to the Law Number 24 of 2003 on the Constitutional Court (Constitutional Court Law of 2011). One of the fundamental changes of the Constitutional Court Law 2011 is to prohibit the Constitutional Court to make ultra petita verdicts.

The prohibition against the Constitutional Court to make ultra petita decisions is stipulated in the provisions of Article 45A and Article 57(2a) of the Constitutional Court Law of 2011. Subsequently, the Constitutional Court declared the law as contradictory to the 1945 Constitution and has no binding legal force. The cancellation of Article 45A and Article 57(2a) is based on the Constitutional Court Decision Number 48/PUU-IX/2011. ${ }^{7}$

The authority of the Parliament to form the norms of the law together with the President can limit the authority of the Constitutional Court. On the other hand, the authority of the Constitutional Court to examine the law against the 1945 Constitution, including making ultra petita decision forming new norms to form

Article 20(1), (2), and Article 21 of The 1945 Constitution of the Republic of Indonesia (the 1945 Constitution). RR. Cahyowati, Loc.cit.

Haeruman Jayadi (ed.), "Kajian Hukum Putusan Ultra Petita Berdasarkan Kewenangan Mahkamah Konstitusi”, this paper is presented as research report for Ministry of Education at Mataram University, 2011, p. 2.

$7 \quad$ Ibid. 
norms that have been canceled, may cause disputes with the Parliament as the legislator.

Based on the description above, this study raises the scope that include several points. The first, what is the task form and the authority of the Parliament and the Constitutional Court according to the 1945 Constitution (constitutionally entrusted power) and the laws (legislatively entrusted power)? In the formulation of this problem, this article aims to re-affirm the position, as well as duties and functions, of both institutions that are stipulated in the 1945 Constitution and the laws. The second, what is the ultra petita authority of the Constitutional Court that causes the redundancy of legislative authority between the Parliament and the Constitutional Court? With the aim to analyze and to reveal the position of both institutions theoretically and juridical constitutionally, it is expected to know the main cause of the legislation authority overlap between the Parliament and the Constitutional Court. In addition, this article also aims to analyze the validity of the ultra petita decisions made by the Constitutional Court.

\section{B. Duties and Authorities of the House of Representatives and Constitutional Court according to the 1945 Constitution (constitutionally entrusted power) and the Laws (legislatively entrusted power)}

To open the analysis, this article explains the definition of ultra petita. Ultra Petita in formal law means the judgment of a case that is not prosecuted, or granted, more than is required. This provision is based on Article 178(2) and (3) of Herzien Indonesisch Reglement (H.I.R) and Article 189(2) and (3) of Rechtsreglement voor de Buitengewesten (RBg). ${ }^{8}$ Meanwhile, according to I.P.M. Ranuhandoko, ultra petita is beyond the requested. ${ }^{9}$ In this article, the ultra petita decision of the Constitutional Court, either constitutional and unconstitutional, as long as the Constitutional Court is out of the theoretical path of its formation as a negative legislator institution by forming a new norm replacing previous norm that has been canceled, causes the overlap of authority in relation to the function of legislation.

On the other hand, the House of Representatives, according to Article 20 of the 1945 Constitution, has the following authority. ${ }^{10}$

1. The House of Representatives has the power to form laws.

2. Every draft of law is discussed by the House of Representatives and the President for mutual consent.

3. If the draft of law is not mutually approved, the draft shall not be brought before the House of Representatives at the period.

4. The President passed a draft of law, which has been mutually agreed to become law.

\footnotetext{
Sekretariat Jenderal dan Kepaniteraan Mahkamah Kontitusi (The Secretariat General and the Secretariat of the Constitutional Court), Hukum Acara Mahkamah Konstitusi, Jakarta: Sekjen MRI, 2006, p. 34 .

I.P.M. Ranuhandoko, Terminologi Hukum, Jakarta: Sinar Grafika, 2000, p. 522.

10 Article 20 of the 1945 Constitution.
} 
5. In an event that a jointly agreed law has not been signed by the President, within thirty days after the draft has been approved, the draft is automatically effective as a law and shall be enacted.

Based on Article 20(1), (2), and Article 21 of the 1945 Constitution, The House of Representatives holds the right to form laws, before the draft is discussed jointly between the House and the President. Further, Article 20A(1) reaffirms that ${ }^{11}$ "Dewan Perwakilan Rakyat memiliki fungsi legislasi, fungsi anggaran, dan fungsi pengawasan" (The House of Representatives has the functions of legislation, budget, and supervisory).

The paragraph reiterates that the power to form a law is entirely in the hands of the Parliament because the 1945 Constitution, juridical-constitutionally, mentions that the only institution with the function of legislation is the House of Representatives. In Bagir Manan's opinion, ${ }^{12}$ the function of legislation is inconsistent with the power of constituting the law. In addition to overlapping, the notion of legislation is broader than the definition of laws. The power to form laws is the only legislative function of the House of Representatives. Therefore, according to Bagir Manan's, the Parliament is the only institution that has legislative function. Therefore, every regulation in Indonesia must involve them, at least acquiring their approval. Furthermore, Article 21 explains that members of the House of Representatives shall have the right to propose a draft of law. Furthermore, the 1945 Constitution reinforces the authority of legislation for the executive in a negative sense. An explanation of this can be seen in Article 22(1) ${ }^{13}$ : Dalam hal ihwal kegentingan yang memaksa, Presiden berhak menetapkan peraturan pemerintah sebagai pengganti undang-undang. [In the case of a pressing incident, the President shall be entitled to stipulate a governmental regulation in lieu of law.]

From the formulation of the article, it can be seen that, basically, the executive institution (the president) has the right to submit draft of Government Regulation in Lieu of Law. However, the draft still has to get an approval from the House of Representatives. This condition is the reason for Prof. Mahfud MD to consider the Executive Board as having legislative authority in a negative sense.

Furthermore, in more detail, the authority of the House of Representatives is also regulated in Law Number 17 of 2014 (MD3 Law). The MD3 Law regulates MPR, DPR, DPD, and DPRD (the People Consultative Assembly, the House of Representatives, the Regional Representative Council, and the Regional House of Representatives). Article 69 of the MD3 Law explains the following. ${ }^{14}$

A. The House of Representatives has functions of:

a) legislation;

\footnotetext{
Article 20A(1) of the 1945 Constitution.

12 Tanto Lailam, "Pro-Kontra Kewenangan Mahkamah Konstitusi dalam Menguji Undang-Undang yang Mengatur Eksistensinya", Jurnal Konstitusi, Vol. 12, No. 4, 2015, p. 299.

13 Article 22(1) of the 1945 Constitution.

14 Article 69 of the Law Number 17 of 2014 on the People Consultative Assembly, the House of Representatives, the Regional Representative Council, and the Regional House of Representatives (MD3 Law).
} 

b) budget; and
c) supervision.

B. The three functions of legislation, supervision, and budget as referred to in Paragraph (1) shall be implemented within the framework of the representation of the people, and also to support the Government's efforts in implementing foreign policy in accordance with the provisions of laws and regulations.

The details of the authority and duties of the House of Representatives as colegislators are contained in Article 71(a) to (e) of the MD3 Law, which states that the House of Representatives is authorized to: ${ }^{15}$

a) establish laws that are discussed with the President for joint approval;

b) give consent or refusal to the government regulation in lieu of the law proposed by the President to become law;

c) discuss the draft of law submitted by the President or the House of Representatives relating to regional autonomy, central and regional relations, the regional establishment and expansion and incorporation, the management of natural resources and other economic resources, as well as the balance of central and regional finances, by involving the Regional Representative Council before collective agreement is taken between the House of Representatives and the President;

d) take into consideration the consideration of Regional Representative Council related to drafts of laws on the State Budget and drafts of laws on taxes, education, and religion;

e) discuss with the President, by taking into consideration the consideration of the Regional Representative Council and giving approval to drafts of laws on the state budget proposed by the President;

On the other hand, the task of Parliament is mentioned in Article 72(a) to (c) which are: ${ }^{16}$

a) compile, discuss, establish, and disseminate national legislation programs;

b) compile, discuss, and disseminate drafts of laws;

c) accept the drafts of laws proposed by the Regional Representative Council in relation to regional autonomy, central and regional relations, regional establishment and expansion and incorporation, the management of natural resources and other economic resources, as well as those related to central and regional financial balances;

\footnotetext{
15 Article 71(a) to (e) of the MD3 Law.
}

16 Article 72 of the MD3 Law. 
The authority of the Constitutional Court is regulated in Article 24C of the 1945 Constitution. It states that: ${ }^{17}$

1. The Constitutional Court has the authority to hear at first and final level where their decision is final to examine laws against the 1945 Constitution, to decide upon the dispute over the authority of the state institutions whose authorities are granted by laws, to decide upon the dissolution of political parties, and to decide upon disputes concerning general election results.

2. The Constitutional Court is obliged to give a decision on the opinion of the House of Representatives regarding alleged violations by the President and/or Vice President based on the 1945 Constitution.

In more detail, the existence and the authority of the Constitutional Court is explicitly regulated in the 1945 Constitution. Based on Article $24 \mathrm{C}(1)$ and (2) of the 1945 Constitution: ${ }^{18}$

Firstly, the Constitutional Court has the authority to hear at the first and final level where the decision is final to:

1. examine the law against the 1945 Constitution.

2. discharge the authority of state institutions that is granted by the 1945 Constitution.

3. decide the dissolution of political parties.

4. resolve disputes concerning general election results.

Secondly, the Constitutional Court is obliged to give a decision on the opinion of the House of Representatives that the President and/or Vice President are alleged to have committed a violation of the law in the form of treason against the state, corruption, bribery, other serious crimes or disgraceful acts, and/or no longer qualifies as President and/ or Vice President according to the 1945 Constitution.

From the provisions contained in the 1945 Constitution, there is no a single authority of the Constitutional Court in establishing the legal norms of legislation. The authority of the Constitutional Court to create legal norms of legislation is regulated in the Constitutional Court Law as the Constitutional Court Regulation. The Constitutional Court's authority in making Constitutional Court Regulation is based on the delegation of authority in the formulation of legislation. ${ }^{19}$

The provision as described in Article $45 \mathrm{C}(1)$ is often the cause of the overlap between the Constitutional Court and the House of Representatives on the authority of the formation of law norms. There are different interpretations between the Constitutional Court and the House of Representatives, which is the subject of this study.

\footnotetext{
Article $24 \mathrm{C}$ of the 1945 Constitution.

18 Article $24 \mathrm{C}(1)$ and (2) of the 1945 Constitution.

19 Jimly Asshidiqqie, Perkembangan dan Konsolidasi Lembaga Negara Pasca Reformasi, Jakarta: Konstitusi Press, 2006, pp. 154-155.
} 
In detail, the authority of the Constitutional Court is regulated in Law Number 24 of 2003 regarding the Constitutional Court (Constitutional Court Law of 2003), Article 10(1) and (2) as follows:

1) The Constitutional Court has the authority to hear at the first and final level the decision is final to: ${ }^{20}$

a. examine a law against the 1945 Constitution of the State of the Republic of Indonesia;

b. decide the dispute over the authorities of state institutions that are granted by the 1945 Constitution of the State of the Republic of Indonesia;

c. decide upon the dissolution of political parties; and

d. decide upon disputes concerning election results.

2) the Constitutional Court is obliged to give a decision on the opinion of the House of Representatives that the President and/or Vice President are alleged to have committed a violation of the law in the form of treason against the state, corruption, bribery, other serious crimes or disgraceful acts, and/or no longer qualifies as President and/or Vice President according to the 1945 Constitution.

From some of the descriptions, based on the principle of trias politica, it can be concluded that the 1945 Constitution has constitutionally distribute the power of legislation to the Legislative and Executive chambers equally. It is in accordance to the concept of checks and balances. Therefore, the pattern of power distribution that is contained in the constitutional system of Indonesia have placed the position of the Constitutional Court and the Supreme Court as state institutions with Judiciary function as enclosed in Article 24(1) and (2) below: ${ }^{21}$

1) Judicial power is an independent power to administer justice to uphold law and justice.

2) Judicial power is exercised by a Supreme Court and the lower courts within the general judiciary, the religious court environment, the military court environment, the administrative court of the state, and by a Constitutional Court.

In the theory of state power, the legislative function has placed the legislative body as the highest authority in terms of legislative formation. The condition is referred by Hans Kalsen as a superordinative function in the power of the State. ${ }^{22}$ Further, Hans Kalsen explains that: ${ }^{23}$

"As we have seen, there are not three but two basic function of the state: creation and application of law, and these functions are not

\footnotetext{
20 Article 10(1) and (2) of the Law Number 24 of 2003 on the Constitutional Court (Constitutional Court Law of 2003).

Article 24(1) and (2) of the 1945 Constitution.

Haeruman Jayadi (ed.), Op.cit., p. 17.

Hans Kalsen, General Theory of Law and State, New York: Russel and Russel, 1973, pp. 269-270.
} 
coordinate but sub and supra-ordinate. Further, it is not possible to define boundary line separating these functions from each order, since the distinction between creation and application of law under lying the dualism of legislative and executive power (in the broadest sense) has only relative character most acts of state being at the same time law creating and law applying acts".

Therefore, based on the above explanation, the subordinate position has placed the power of legislative formation in the hands of a legislative chamber. Its application is in the hands of the executive. Nailing this position is an essential essence of adopting a classical theory called trias politica. ${ }^{24}$

Then, in the current situation, the state administration system is not absolutely follow the principle of trias politica. No matter how strong the separation is, the principle of power separation must gradually encounter another power. The present fact shows that the relationship between power branches is impossible not to touch each other, even the all three are equal and control each other in accordance with the principle of checks and balances. On this basis, then the supra-ordinative power of the legislative institution is merged to other institutions such as the executive and the judiciary. In accordance with Article 24C of the 1945 Constitution, one of the powers granted to the Constitutional Court is "to examine law against the 1945 Constitution". ${ }^{25}$ However, the mechanism of fusion of authority is intended to balance the affairs of state so that every institution can help each other but not to take authority, because the step is certainly contradictory both theoretically and constitutionally. ${ }^{26}$

\section{Form of Ultra Petita Authority that Causes the Overlap of Legislative Authority between the House of Representatives and the Constitutional Court}

The focus of the study is various ultra petita verdicts in the judicial reviews of laws against the 1945 Constitution. Based on the 1945 Constitution in Article 24C(1), "The Constitutional Court has the authority to hear at first and final level where their decision is final to examine laws against the 1945 Constitution, to decide upon the dispute over the authority of the state institutions whose authorities are granted by laws, to decide upon the dissolution of political parties, and to decide upon disputes concerning general election results."

Based on the provisions of the aforementioned article, the Constitutional Court is given the authority to examine laws against the 1945 Constitution. The word examine means that the Constitutional Court has the authority to assess whether a law is in accordance or not against the 1945 Constitution. ${ }^{27}$ This assessment is

24 Montesqieu, The Spirit of Laws: Dasar-Dasar Ilmu Hukum dan Ilmu Politik, Bandung: PT Nusa Media, 2007, p. 13.

25 Jimly Asshidiqqie, Op.cit., p. 36.

26 Bagir Manan, Lembaga Kepresidenan, Yogyakarta: FH UII Press, 2006, p. 8.

27 Janedri M. Gaffar, Demokrasi Konstitusi Praktik Ketatanegaraan Indonesia Setelah Perubahan UUD 1945, Jakarta: Konstitusi Press, 2012, p. 109. 
done so that laws established by the Parliament together with the President is not contradictory to the 1945 Constitution as the highest legislation in the Republic of Indonesia.

As previously referred, the Constitutional Court only has the authority to declare a law or part of a law either substantively or procedurally contrary to the 1945 Constitution or not. ${ }^{28}$ Thus, the 1945 Constitution does not regulate the Constitutional Court's authority to establish a new norm to replace the abrogated norm.

Based on Article 56 and 57 of the Constitutional Court Law of 2003, the form of the Constitutional Court's decision on the petition for judicial review of law against the 1945 Constitution is as follows: ${ }^{29}$

a) Where the Constitutional Court is of the opinion that petitioner and/or the petition does not meet the requirements as applicable, the decision declares the petition unacceptable (Article 56(1)).

b) In the case where the Constitutional Court is of the opinion that the petition is reasonable, the decision declares the petition to be granted (Article 56 paragraph [2]).

c) In the case of the law formation, when the law formation does not meet the provisions of formulation under the 1945 Constitution, the decision declares the petition to be granted (Article 56(4)).

d) In the event that the law is not contradictory to the 1945 Constitution, neither concerning the formation or the material in part or in whole, the decision declares the petition to be rejected (Article 56(5)).

e) Decision of the Constitutional Court that the decree declares the contents of paragraphs, articles and/or parts of the law is contradictory to the 1945 Constitution, the content of paragraphs, articles and/or parts of the law does not have binding legal force (Art 57 (1)).

f) Decision of the Constitutional Court that the decree declares the formulation of the law does not meet the provisions of the law formulation under the 1945 Constitution, the law has no binding legal force (Article 57(2)).

The provisions of the Constitutional Court Law of 2003 above show that the Constitutional Court is not authorized to form a new norm in lieu of norms that have been canceled. With the authority to cancel the provisions of law, the nature of the work of the constitutional justice institution, according to Hans Kelsen, is more related to the function of making law. The Constitutional Court, for Hans Kelsen, is more concerned with the function of legislation than the judiciary. When canceling a provision of a law, in essence, the Constitutional Court also creates a new norm with the abolition of the old norm. Therefore, Hans Kelsen calls this negative legislator that

\footnotetext{
28 Ibid.

29 Article 56 and 57 of the Constitutional Court Law of 2003.
} 
is very different from the parliament that runs the function of positive legislator. ${ }^{30}$ In the view of John Ferejohn and Pasquale Pasquino, in essence, the Constitutional Court also serves as a positive legislator. ${ }^{31}$

This study takes Hans Kelsen's opinion that the Constitutional Court is a negative legislator. It is in accordance with general knowledge that legislation is a task of parliament, which is representative of the people. The opinion of John Ferejohn and Pasquale Pasquino, which consider the Constitutional Court as a positive legislator, is not appropriate.

At least two things are violated when the Constitutional Court functions as a positive legislator. They are the principles of power separation or distribution and positive law -applicable in this case is the Constitutional Court Law of 2003. If the Constitutional Court also serves as a positive legislator, it is contradicted to the principle of power separation or sharing. It is because, basically, the position of a positive legislator is in the hands of a legislative body (the parliament), as representatives elected by the people. From the aspect of positive law, the Constitutional Court Law of 2003 regulates the form of the Constitutional Court decisions in three types: unacceptable, granted, and rejected. This means that if the Constitutional Court grants a petition, it must be in accordance with the intention of the petitioner. The 2003 Constitutional Court Law does not open the possibility of a decision beyond points that are petitioned by the petitioner. ${ }^{32}$

Then, in 2011, the House of Representatives and the President have promulgated the Constitutional Court Law of 2011. In essence the House of Representatives looks to limit the ultra petita authority of the Constitutional Court. It was intended to prohibit the Constitutional Court in making ultra petita verdicts. This is stipulated in Article 45A, which mentions that the decision of the Constitutional Court may not contain the rulings that the petitioner does not request or exceed the petitioner's petition, except on certain matters related to the subject matter of the request. Furthermore, Article 57 explains the following: ${ }^{33}$

1) Decision of the Constitutional Court that the decree declares the contents of paragraphs, articles and/or parts of the law is contradictory to the 1945 Constitution, the content of paragraphs, articles and/or parts of the law does not have binding legal force.

2) Decision of the Constitutional Court that the decree declares the formulation of the law does not meet the provisions of the law formulation under the 1945 Constitution, the law has no binding legal force.

30 Jimly Asshidiqqie, Pokok-Pokok Hukum Tata Negara Indonesia Pasca Reformasi, $2^{\text {nd }}$ printing, Jakarta: Bhuana Ilmu Populer, 2008, p. 592.

lbid. p. 593.

Jimly Asshidiqqie, Hukum Tata Negara dan Pilar-Pilar Demokrasi, $2^{\text {nd }}$ printing, Jakarta: Sinar Grafika, 2012, p. 12. Article 57 of the Law Number 8 of 2011 on the Amendment to the Law Number 24 of 2003 about the Constitutional Court (Constitutional Court Law of 2011). 
A. The decision of the Constitutional Court does not contain:

a. rulings other than as intended in paragraphs (1) and (2);

b. orders to lawmakers; and

c. formulation of norms in lieu of norms of laws that are contradictory to the 1945 Constitution of the Unitary State of the Republic of Indonesia.

Therefore, based on the provisions of Article 45A and 57(2A), the Constitutional Court is prohibited to: ${ }^{34}$

a. Make a verdict beyond the petition requested, except for certain matters related to the principal of the petition.

b. Make orders to the lawmakers.

c. Create new norms in lieu of norms that have been banned.

The above three forms of prohibition show that ultra petita decision is not prohibited absolutely. This can be known from the Article 45A. In Article 45A, there is an exception for certain matters related to the principal of the petition. As an example, in the judicial review of the Law Number 20 of 2002 on electricity, the petitioners requested the cancellation of Article 16, 17(3), and 68 of the Law. The Constitutional Court decided as follows: ${ }^{35}$

"Considering whereas even though the provisions deemed to be contradictory to the constitution are essentially Article 16, 17(3), and 68, especially those concerning unbundling and competition, but because those articles are at the heart of Law Number 20 of 2002. Whereas the whole paradigm underlying the Law on Electricity is contest or competition in management with unbundling system in electricity, which is reflected in the consideration of the letter $b$ and $c$ of the Electricity Law. It is not in accordance with the essence and the spirit of Article 33(2) of the 1945 Constitution, which is the basic norm of Indonesia's national economy. Considering whereas since Articles 16 and 17 are declared contradictory to the 1945 Constitution, which resulted in Law Number 20 of 2002 as a whole is declared to have no legally binding force because the underlying paradigm is contradictory to the 1945 Constitution ".

Based on the above example, this ultra petita verdict can be justified because the articles which were requested to be aborted are the articles that become the foundation/heart of other articles. Therefore, the foundation/heart of the law is canceled to make the law ineffective to be carried out. In terms of the second form of prohibition that the Constitutional Court cannot make a decision that orders the legislators is more on political considerations.

34 Article 45A and Article 57(2A) of the Constitutional Court Law of 2011.

35 Decision of the Constitutional Court Number 001-021-022/PUU-1/2003, p. 349. 
The legislators (the parliament and the president) feel inferior when the Constitutional Court, in its decision, orders the House and the President as the lawmakers to prepare law replacement or amendment. Some decisions of the Constitutional Court that contain commands to the lawmakers are as follows:

a. Considering whereas with the enactment of the Law Number 20 of 2002 has no binding legal force, it is recommended that the legislators prepare a new Electricity Law in accordance with Article 33 of the 1945 Constitution. ${ }^{36}$

b. "...... Therefore, the Constitutional Court also recommends to the House of Representatives and the President immediately to take measures to improve the Law on Judicial Commission. In fact, the House of Representatives and the President are also encouraged to make improvements that are integral to also make changes in the framework of harmonization and synchronization of the Laws on Judicial Commission, Supreme Court, Constitutional Court, and other laws related to the integrated judicial system... ". 37

The Constitutional Court in its decision is prohibited to create a new norm as a substitute for abandoned norms. The example is the Decision of the Constitutional Court Number 102/PUU-VII/2009. The decree contains decisions on the judicial review of Law Number 42 of 2008 on the General Election of President and Vice President as follows: ${ }^{38}$

To declare Article 28 and Article 111 of Law Number 42 of 2008 on General Election of President and Vice President (Election of President and Vice President Law of 2008) is constitutional as long as it is meant to include citizens who are not registered in the final voters list with the following terms and conditions:

1. In addition to Indonesian citizens registered in the final voters list, Indonesian citizens who have not registered in the final voters list may exercise their right to vote by presenting a valid identity card or a valid passport of indonesian citizens abroad;

2. Indonesian citizens who use ID cards must also provide family card or similar documents;

3. The use of voting rights for Indonesian citizens using valid ID cards may only be used in polling stations located in neighborhood/ hamlet or similar levels in accordance with the address stated on their ID card;

4. Indonesian citizen as mentioned in point 3 above, before exercising his/her right to vote, must be registered in local polling committee;

5. Indonesian citizen who will exercise his/her right to vote by ID Cards or Passport shall be conducted within 1 (one) hour before the completion of voting at the local or abroad polling station.

Ibid. p. 350.

Decision of the Constitutional Court Number 005/PUU-IV/2006, p. 201.

Decision of the Constitutional Court Number 102/PUU-VII/2009, pp. 19-20. 
The five ways and conditions mentioned above are new norms that substituted norms that were canceled by the Constitutional Court. The new norm should not be created by the Constitutional Court because, based on the 1945 Constitution and the Constitutional Court Law of 2003, the Constitutional Court does not have the authority to form a new norm. About the concerns about the legal vacuum due to the cancellation, the President based on the 1945 Constitution can take a constitutional solution. The President can issue government regulation in lieu of law to overcome the circumstances that arise after the abortion of Article 28 and Article 111 of the Election of President and Vice President Law of 2008. Some of the conditions established by the Constitutional Court in the decision above is the examples of ultra petita authority of the Constitutional Court. They have caused overlaps of legislative authority between the Parliament and the Constitutional Court. The ultra petita form of the Constitutional Court, which may establish or add new norms to a law, violates the principle of check and balance. The ultra petita verdicts can obviously disrupts the implementation of legislative functions of the Parliament. Theoretically, the Constitutional Court and the Supreme Court are allowed to participate in the discussion and the making of a law, but not in the courts. The Constitutional Court and the Supreme Court can only be presented in the Parliament sessions that discuss a draft of law.

Therefore, the Constitutional Court cannot form a new norm as a consideration for the legislators in fixing a law that has been canceled in a conditional constitutional decision. It is not appropriate to be attached and mentioned in the Constitutional Court's decision. The Constitutional Court can only make four decisions: "petition rejected", "petition unacceptable", "petition granted", and "materials of content, paragraph, article, and/or a law has no binding legal force".

The Constitutional Court in the Decision of the Constitutional Court Number 005/PUU-IV/2006 has actually recognized this condition. The Constitutional Court states that:

"...the task of legislation is the duty of the House of Representatives, together with the government. The Supreme Court, the Constitutional Court, and the Judicial Commission are the implementing agencies of the law so they must submit all matters of legislation to the legislator. That the Supreme Court, the Constitutional Court, and the Judicial Commission can be included in the process of forming a law that will govern itself is of course a logical one. However, it is not a constitutional duty of the Supreme Court, the Constitutional Court, and the Judicial Commission to take an open-ended initiative to amend the law as intended. Each State institution should have restricted itself to do work that is not the main task, unless it is only intended as a supporter ". ${ }^{39}$

Decision of the Constitutional Court Number 005/PUU-IV/2006, p. 201. 
However, the prohibition against the Constitutional Court to make an ultra petita decision as stipulated in the provisions of Article 45A and 57(2a) of the Constitutional Court Law of 2011 is then declared contrary to the 1945 Constitution and has no binding legal force. The cancellation of Articles 45A and 57(2a) is based on the decision of Constitutional Court Number 48/PUU-IX/2011. In its legal considerations, the Constitutional Court declared several positions that annul the provisions in Article $45 \mathrm{~A}$ and 57(2A) as follows: ${ }^{40}$

a. Because of the public interest.

b. The articles are the core article of the law.

c. Based on the principle of ex aequo et bono, the judge may impose fair and proper judgments.

d. To guard against legal vacuum.

e. Carry out the obligations of constitutional justices to explore, follow, and understand the legal values and sense of justice living in the community.

The cancellation of the provisions of Article 45A and 57(2a) of the Constitutional Court Law of 2011 to make ultra petita decision. The cancellation of the provision has the potential to cause a prolonged and uninterrupted dispute between the Constitutional Court as an institution authorized to examine the law against the 1945 Constitution versus the House of Representatives and the President as the institutions that form laws. ${ }^{41}$

This condition indicates the overlap of authority between the Constitutional Court and the House of Representatives. The Article 45A and 57(2a) of the Constitutional Court Law of 2011 were intended by the Government and the Parliament to limit the authority of the Constitutional Court. It was to prohibit the Constitutional Court to go too far in using the ultra petita power. However, the Constitutional Court canceled the law. So far, there is no a constitutional legal mechanism that can be done by the parliament or the government to limit the use of ultra petita.

The judicial review against the provisions of Article 45A and Article 57(2a) of the 2011 Law above is contrary to the principle of nemo judex idoneus in propria causa. ${ }^{42}$ The principle emphasizes that no one can be a judge in his own case. It is one the legal principles of the Constitutional Court, the embodiment of impartiality of the judge as a justice giver. ${ }^{43}$ However, in the Constitutional Court's decision, there is no explanation on the violation of this principle but this principle is the principal principle in the trial of a judicial institution.

The implications of some of these decisions are the pros and cons on the authority of the Constitutional Court. The Constitutional Court should not have the authority to examine the laws governing its existence because of the clash between

Decision of the Constitutional Court Number 48/PUU-IX/2011, pp. 91-94.

Haeruman Jayadi (ed.), Op.cit., p. 68.

Ibid.

43 Ali Taher Parasong, Mencegah Runtuhnya Negara Hukum, Jakarta: Grafindo Books Media, 2014, p. 166. 
the principle of ius curia novit and the principle of nemo judex idoneus in propria causa (the judge should not examine cases involving himself) may put its own interests first. In short, it makes them very difficult to be impartial. ${ }^{44}$ In addition, due to the many judgments of the Constitutional Court, sometimes a decision is considered as "legal breakthrough" because it provides fresh law enforcement and justice. However, sometimes the decision is also considered as "legal crush" because it is considered too dry from the values of justice and morality of the constitution and is deviated from the law reform. ${ }^{45}$ However, because the nature of the Constitutional Court's decision is final and binding and the absence of other legal remedies, the Constitutional Court's decision is inevitably regarded as "legal truth", although it still leaves legal problems.

\section{Ultra Petita Decision in Relation to the Principle of Power Separation of based on the Principle of Check and Balance}

In this part, the ultra petita decision of the Constitutional Court will further be examined by using the principle of power separation based on the principle of check and balance.

State institutions based on their respective functions and authorities exercise power within a state. In Indonesia, the legislative power is in the hands of the parliament, the executive power is the president, and the judicial power is the Supreme Court and the Constitutional Court. These three branches of power have an equal position with each other. These three branches of power are in a position of mutual control and balance. ${ }^{46}$

The House of Representatives as the holder of legislative power must jointly with the president in formulating the law. The legislation forming jointly between the House and the President shall be guarded by the Constitutional Court so as not to conflict with the constitution through the mechanism of the Act against the constitution. In the case of impeachment against the president and / or vice president, the House of Representatives must take legal action through a trial in the Constitutional Court before filing a presidential and / or vice president's dismissal to the MPR ${ }^{47}$ The aforementioned forms of relationship reflect that the three branches of power have a close relationship that is equal and mutually compensates and controls one another.

The authority of the judicial review of the Law against the 1945 Constitution is granted to the Constitutional Court, while the authority of testing the laws and regulations is granted to the Supreme Court. In the case of judicial review of the law against the 1945 Constitution, the nature of the Constitutional Court's decision is final so that there is no legal remedy against the Constitutional Court's decision. In addition, the Constitutional Court is the first and last court in the judicial review of

Ibid.

Moh. Mahfud MD, Konstitusi dan Hukum dalam Kontroversi Isu, Jakarta: Rajawali Press, 2012, p. 255.

Ali Taher Parasong, Op.cit., p. 164.

Haryatmoko, Etika Politik dan Kekuasaan, Jakarta: PT Kompas Media Nusantara, 2014, p. 237. 
the law against the 1945 Constitution. There is no court of appeal and cassation like the judicial in the Supreme Court. ${ }^{48}$

Because the Constitutional Court is the first and final judiciary that the decision is final in the judicial review of law against the 1945 Constitution, the authority must be exercised with caution. There should no abuse in it because it will result a very wide effect in the life of the nation and state. Its relationship with the Supreme Court decision in the judicial review of the law against the 1945 Constitution has caused pros and cons within the people, especially the legal experts. ${ }^{49}$

Based on the principle of power separation with the principle of check and balance, the ultra petita decision of the Constitutional Court that form new norms to replace aborted norms is a violation on the principle. The parliament and the president are the parties that should form the law together. ${ }^{50}$

Therefore, the authority to make public binding norms in the form of Law is in the hands of the House of Representatives and the President. This is what is termed as legislation, whereas the Constitutional Court is only given the authority to examine the Law against the 1945 Constitution. Consequently, the nature of the Constitutional Court's authority is to assess whether a law is contrary to the 1945 Constitution or not. If the Constitutional Court believes that a law or part of it is contrary to the constitution, the Constitutional Court cancels the law or its part by declaring it has no binding legal force and the position of the Constitutional Court in this case is referred to as a negative legislator.

If the Constitutional Court also has a function of legislation, it has denied or contradicted the principle of power separation or distribution since, in essence, the position of positive legislator is in the hands of the legislative body (the parliament) as a representative elected by the people. In addition, if the Constitutional Court acts as a legislator, as well as the House of Representatives and the president that are given the authority by the 1945 Constitution, the Constitutional Court holds two functions of power at the same time. They are legislative and judicial power. This surely violates the principle of power separation with the principles of check and balance that place the three powers in an equal position to supervise each other and to have balance according to their respective powers. Based on the objective of power separation, which is to prevent the absolutism caused by the concentration of power, then the authority of the Constitutional Court through its decision to create a new norm, which should be regulated in the law, will generate a buildup of power so that can cause absolutism. ${ }^{51}$

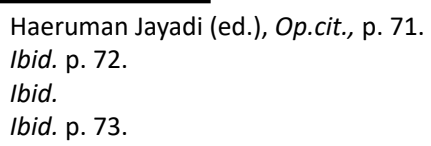




\section{E. Conclusion}

The 1945 Constitution regulates the principle of trias politica by distributing authority and responsibility to each state institution in the administration system of Indonesia. Although its application is not fully accommodated, it is stated explicitly in the constitution that the power to form law is in the hand of legislative (the House of Representatives) and the executive (the President) in accordance with what is contained in the provisions of Article 20(1) of the 1945 Constitution.

In some cases, the Constitutional Court has repeatedly issued ultra petita verdicts. This condition causes overlap of legislative authority between the House of Representatives and the Constitutional Court. The ultra petita verdicts have several forms, including:

a. Making a decision beyond the petition;

b. Making orders to lawmakers (the House of Representatives and the President); and

c. Creating a new norm to replace the canceled norm.

Based on the principle of power separation with the principle of check and balance, the Constitutional Court's ultra petita decisions that resulted new publicly binding norm in place of abandoned norm has denied the principle of power separation with the principle of check and balance. It is because, essentially, legislative institutions are the Parliament (the People Consultative Assembly, the House of Representatives, the Regional Representative Council, and the Regional House of Representatives). The Constitutional Court only serves as a negative legislator. The Constitutional Court's authority to establish a new norm in place of the canceled norm can be considered as a unilateral takeover of legislative authority.

\section{F. Suggestions}

The regulation of the Constitutional Court's unconstitutionality in making ultra petita decisions shall have constitutional guarantees of the 1945 Constitution. Therefore, it should be contained in the Constitutional Court's authority as provided in the 1945 Constitution, where there should be the next amendment for the 1945 Constitution.

The Constitutional Court should respect the practice of separation power in the administration system of Indonesia. The Constitutional Court can form a decision that is progressive, but not necessarily opposing to the standard principles known in the world of justice. The ultra petita steps taken by the Constitutional Court in some cases as described above are unconstitutional because the Constitutional Court has placed itself as a legislative body. It is surely contrary to the provisions of Article 20 of the 1945 Constitution.

\section{References}

\section{Books}

Ali Taher Parasong, Mencegah Runtuhnya Negara Hukum, Grafindo Books Media, Jakarta, 2014. 
Bagir Manan, Lembaga Kepresidenan, FH UII Press, Yogyakarta, 2006.

Haryatmoko, Etika Politik dan Kekuasaan, PT Kompas Media Nusantara, Jakarta, 2014.

I.P.M. Ranuhandoko, Terminologi Hukum, Sinar Grafika, Jakarta, 2000.

Janedri M. Gaffar, Demokrasi Konstitusi Praktik Ketatanegaraan Indonesia Setelah Perubahan UUD 1945, Konstitusi Press, Jakarta, 2012.

Jimly Asshidiqqie, Hukum Tata Negara dan Pilar-Pilar Demokrasi, $2^{\text {nd }}$ printing, Sinar Grafika, Jakarta, 2012.

,Perkembangan dan Konsolidasi Lembaga Negara Pasca Reformasi,

Konstitusi Press, Jakarta, 2006. , Pokok-Pokok Hukum Tata Negara Indonesia Pasca Reformasi, $2^{\text {nd }}$ printing, Bhuana Ilmu Populer, Jakarta, 2008.

Kalsen, Hans, General Theory of Law and State, Russel and Russel, New York, 1973.

Moh. Mahfud MD, Konstitusi dan Hukum dalam Kontroversi Isu, Rajawali Press, Jakarta, 2012.

Montesqieu, The Spirit of Laws, Dasar-Dasar IImu Hukum dan IImu Politik, PT Nusa Media, Bandung, 2007.

The Secretariat General and the Secretariat of the Constitutional Court, Hukum Acara Mahkamah Konstitusi, Sekjen MKRI, Jakarta, 2006.

\section{Other Documents}

Haeruman Jayadi (ed.), "Kajian Hukum Putusan Ultra Petita Berdasarkan Kewenangan Mahkamah Konstitusi", this paper is presented as research report for Ministry of Education at Mataram University, 2011.

Jimly Asshidiqqie, "Kedudukan Mahkamah Konstitusi Dalam Struktur Ketatanegaraan Indonesia", http//www.jimlyschool.com, accessed on September 2017.

RR. Cahyowati (ed.), "Sengketa Kewenangan Antara Dewan Perwakilan Rakyat Dan Mahkamah Konstitusi Dalam Pembentukan Norma Hukum", Jurnal Penelitian Universitas Mataram, Vol. 18, No. 2, 2014.

Tanto Lailam, "Pro-Kontra KewenanganMahkamah Konstitusi dalam Menguji Undang-Undang yang Mengatur Eksistensinya", Jurnal Konstitusi, Vol. 12, No. 4, 2015.

\section{Legal Documents}

The 1945 Constitution of the Republic of Indonesia.

Herziene Indonesich Reglement.

Rechtsreglement voor de Buitengewesten.

Law Number 24 of 2003 on the Constitutional Court.

Law Number 42 of 2008 on General Election of President and Vice President.

Law Number 8 of 2011 on the Amendment to the Law Number 24 of 2003 on the Constitutional Court. 
Law Number 17 of 2017 on the People Consultative Assembly, the House of Representatives, the Regional Representative Council, and the Regional House of Representatives.

Decision of the Constitutional Court Number 001-021-022/PUU-I/2003.

Decision of the Constitutional Court Number 005/PUU-IV/2006.

Decision of the Constitutional Court Number 102/PUU-VII/2009.

Decision of the Constitutional Court Number 48/PUU-IX/2011. 